\title{
ПРОБЛЕМА ДВОЙНОГО ГРАЖДАНСТВА КАК ПОЛИТИКО-ПРАВОВОЙ ВЫЗОВ СОЦИОГУМАНИТАРНОЙ БЕЗОПАСНОСТИ
}

\begin{abstract}
Аннотация: Институт двойного гражданства порождает гуманитарно-политические разногласия и политико-правовые коллизии прежде всего вследствие разного объема прав и свобод, которыми бипатриды (лица с двумя гражданствами) могут реально пользоваться по месту проживания и на которые они имеют право согласно законам своей (этнической и т.п.) родины, гражданами которой они также остаются. Вследствие этого на протяжении последних полутора столетий в практике межгосударственных отношений сложилась тендениия избегать применение института двойного гражданства, а в случае невозможности - пользоваться им только на основе двусторонних соглашений. Особенно - 6 контексте региональных интеграционных процессов - это касается политико-гуманитарной безопасности стран «новой демократии» (в частности России и Украины). Более того, в непростых постсоветских реалиях, осложненных этнонаииональными конфликтами в Приднестровьи и на Кавказе, проблема (двойного) гражданства как фактор национальной безопасности имеет по меньшей мере три аспекта - политико-правовой, сочиально-политический и евроинтеграционный. Review: The institution of dual citizenship causes humanitarian and political frictions and political legal collisions due to the differences in the amount of freedoms and rights, which dual nationals may really have at the place of their residence and to which they are entitled under the laws of their (ethnical, etc.) motherland, citizenship of which they still have. Due to this issue, in last 150 years the practice of the international relations tends to avoid application of the dual citizenship, and if it is not possible to entirely avoid it - to use it based on bilateral treaties. This is especially relevant within the context of regional integration processes and political - humanitarian security of the "new democracies" (including Russia and Ukraine). Moreover, in the complicated post-Soviet reality, which is made even more difficult by the ethnic and national conflicts in the Trandniestria and the Caucasus, the problem of dual citizenship as a national security factor has at least three dimensions: political legal; social political and European integration.
\end{abstract}

Ключевые слова: Политология, гражданство, государство, безопасность, бипатриды, интеграиия, коллизия, глобализачия, Европа, Закон

Keywords: political science, citizenship, state, security, dual nationals, integration, collision, globalization, Europe, law.

Будь гражданином, ибо родина нужна для твоей безопасности, для твох удовольствий, для твоего благополучия.

К.А. Гельвеций (1685-1755)

Граждане смешанного государства походят на ступеньки, которые все равны, но поставлены одна над другою.

Пьер Буаст (1765-1824)

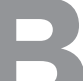

условиях трансформации феноменов государственности ${ }^{1}$ и национальной идентичности (в ее политико-правовом измерении) ${ }^{2}$ проблемы гражданства ${ }^{3}$ приобретают принципиальное значение. Последние десятилетия связаны

\footnotetext{
${ }^{1}$ Ср. Кокошин А.А. Реальный суверенитет. - М: Европа, 2006. - 180 с.; Суверенитет: Антология. - М.: Европа, 2007. - 304 с.

${ }^{2}$ См. Полтораков А.Ю. «Европейская идентичность» и «европейские ценности» в политико-правовом поле Европейского Союза // Цивилизационная структура современного мира. Коллективная монография. / Под ред. ак. НАН Украины Ю. Пахомова и д.филос.н. Ю. Павленко - К.: Наукова думка, 2007. - Т.ІІ.Макрохристианский мир в эпоху глобализации.

Полтораков А.Ю. Цивилизационные проблемы западноевропейской интеграции и вопросы национально-государственной идентичности // Цивилизационная структура современного мира.
}

Коллективная монография. / Под ред. ак. НАН Украины Ю. Пахомова и д.филос.н. Ю. Павленко - К.: Наукова думка, 2007. - Т.ІІ. Макрохристианский мир в эпоху глобализации.

${ }^{3}$ См. Бархатова Е.Ю. Гражданство и регистрация: Москва, Россия, СНГ. - 2.изд., перераб. и доп. - М.: ТК Велби; Проспект, 2005. - 397 c.

Бедрій Р.Б. Громадянство України: конституційно-правові основи: Автореф. дис... канд. юрид. наук: 12.00.02 / Національна академія внутрішніх справ України. - К., 2005. - 16 с.

Белов А.В. Двойное гражданство и проблема лояльности // Правоведение. - 2002. - № 2. - С. 157-161. 


\section{Право и политика $8(164) \cdot 2013$}

с активным развитием института гражданства ${ }^{4}$. В области гражданства в международном праве складываются определенные унифицированные подходы, своего рода «стандарты». Уже несколько десятков лет человечество является свидетелем появления гражданства нового типа - гражданства в рамках интеграционных образований ${ }^{5}$. Наметившиеся политико-правовые тенденции связаны не только с дальнейшим развитием кодификационного процесса в этой области (наглядным примером этого может служить появление Европейской конвенции о гражданстве 1997 г.), но и также с углублением и расширением методологического аппарата института гражданства и перенесением его в новую плоскость, где актуализируются аспекты, связанные с гуманитарно-политической безопаностью ${ }^{6}$.

Особенно - в контексте региональных интеграционных процессов - это касается политико-гуманитарной безопасности стран «новой демократии» (в частности России и Украины $)^{7}$. Более того, в непростых постсоветских реалиях, осложненных этнонациональными конфликтами в Приднестровьи и на Кавказе, проблема (двойного) гражданства как фактор национальной безопасности имеет по меньшей мере три аспекта - политико-правовой, социально-политический и евроинтеграционный.

\section{Политико-правовые аспекты двойного гражданства}

Согласно общей теории государства и права, под гражданством понимается постоянная правовая связь личности и государства, которая находит свое проявление у них взаимных правах и обязанностях ${ }^{8}$. Такая связь возникает,

${ }^{4}$ См. Рубач Л., Мілорава М., Кочюба В. Громадянство: набуття та припинення / Центр правових досліджень Фурси. - К. : Видавець Фурса С.Я., 2006. - 68c.

Умови громадянства: Збірка статей / Б. ван Стінберген (ред.), О.О. Іваненко (пер.). - К. : Український Центр духовної культури, 2005. - 264c.

${ }^{5}$ Ср. Полтораков О.Ю. Адаптація розвитку «простору СНД» до умов глобалізації // Глобалізація і глобальне управління: історичний, соціальний та політологічний виміри. Матеріали міжвідомчої науково-практичної конференції / Відп. ред. С.О. Шергін - К.: Центр вільної преси, 2009.

${ }^{6}$ См. Белов А.В. Международно-правовые аспекты двойного гражданства : Автореферат диссертации на соискание ученой степени кандидата юридических наук. Специальность 12.00.10 Международное право ; Европейское право / Санкт-Петербургский государственный университет. - СПб., 2002. - с.4.

${ }^{7}$ Бархатова Е.Ю. Гражданство и регистрация: Москва, Россия, СНГ. - 2.изд., перераб. и доп. - М.: ТК Велби; Проспект, 2005. - 397 с.

${ }^{8}$ Бедрій Р.Б. Громадянство України: конституційно-правові основи: Автореф. дис... канд. юрид. наук: 12.00.02 / Національна академія внутрішніх справ України. - К., 2005. - с3-7. как правило, с рождением человека и сохраняется на протяжении всей его жизни 9 . Государство гарантирует своим гражданам обеспечение прав и свобод. В свою очередь граждане, находясь под защитой государства, принимают на себя определенные обязанности. В специальной научноправовой литературе ${ }^{10}$ выделяют два вида гражданства - государственно-правовой (внутригосударственный) и международно-правовой (межгосударственный), причем ряд ученых нормы, посвященные двойному гражданству стали выделять в самостоятельный институт права институт двойного гражданства ${ }^{11}$. Европейская конвенция о гражданстве (1997 г.) устанавливает, что множественное гражданство означает одновременное наличие у одного и того же лица двух или более гражданств» (ст. 2) ${ }^{12}$. Аналогичное определение содержит Закон «О гражданстве Российской Федерации» (2002 г.) $)^{13}$.

В современных условиях глобализации на межстрановый уровень выходит проблема множественного (в частности - двойного) гражданства. Отношение к такому гражданству в разных странах разное и продиктовано развитием государства, степенью вовлеченности его в международные институты, местом в гео-политике, гео-экономике и гео-культуре (Е.Быстрицкий). В первом приближении, государственные подходы к проблеме

${ }^{9}$ См. Рубач Л., Мілорава М., Кочюба В. Громадянство: набуття та припинення / Центр правових досліджень Фурси. - К. : Видавець Фурса С.Я., 2006. - 68c.

${ }^{10}$ Бархатова Е.Ю. Гражданство и регистрация: Москва, Россия, СНГ. - 2.изд., перераб. и доп. - М.: ТК Велби; Проспект, 2005. $397 \mathrm{c}$.

Бедрій Р.Б. Громадянство України: конституційно-правові основи: Автореф. дис... канд. юрид. наук: 12.00.02 / Національна академія внутрішніх справ України. - К., 2005. - 16 с.

Белов А.В. Двойное гражданство и проблема лояльности // Правоведение. - 2002. - № 2. - С. 157-161.

Белов А.В. Международно-правовые аспекты двойного гражданства : Автореферат диссертации на соискание ученой степени кандидата юридических наук. Специальность 12.00.10 - Международное право ; Европейское право / Санкт-Петербургский государственный университет. - СПб., 2002. - 23 с.

Кутафин О.Е. Российское гражданство. - М. : Юрист, 2004. - 589 с. Рубач Л., Мілорава М., Кочюба В. Громадянство: набуття та припинення / Центр правових досліджень Фурси. - К. : Видавець Фурса С.Я., 2006. - 68c.

${ }^{11}$ См. Белов А.В. Двойное гражданство и проблема лояльности // Правоведение. - 2002. - № 2. - С. 157-161.

Белов A.B. Международно-правовые аспекты двойного гражданства : Автореферат диссертации на соискание ученой степени кандидата юридических наук. Специальность 12.00.10 - Международное право ; Европейское право / Санкт-Петербургский государственный университет. - СПб., 2002. - 23 с.

${ }^{12}$ Европейская конвениия о гражданстве от 6 ноября 1997 г. // European Treaty Series. - № 166.

13 Федеральный закон Российской Федерации «О гражданстве Российской Федерации» от 31 мая 2002 г. № 62-Ф3 // Российская газета. - 2002. - 5 июня. - № 100. 
двойного гражданства ${ }^{14}$ можно разбить на три категории - «позитивную», «нейтральную» (к которой примыкает «нейтрально-негативная») и «негативную».

Страны, которые можно отнести к первой - «позитивной» - категории, свободно признают за своим гражданином право на получение одновременно гражданства других стран, (например, Великобритания, Ирландия, Франция, Испания, Канада и др.; в 2002 г. получили право двойного гражданства граждане Австралии и Эквадора). Так, ст. 11 Конституции Испании гласит: «Государство может заключать договоры о двойном гражданстве с ибероамериканскими странами или со странами, которые имели или имеют особые связи с Испанией. В этих же странах, даже если они не признают за своими гражданами такого права на взаимной основе, испанцы могут натурализоваться без потери своего гражданства по рождению».

Многие государства Южной Азии сознательно допускают накопление гражданств, создавая значительно облегченные условия для получения гражданства представителям ассимилированных этнических групп. При подобной натурализации членов многочисленных чуждых этнонациональных меньшинств надеются решить их проблемы, поощряя процесс их включения в общество.

Вторая - «нейтральная»-группа государств допускает двойное гражданство или не требует отказа от прежнего гражданства при предоставлении нового (Бельгия, Италия, Нидерланды, США, Франция и др.).

Так, в США установилась юридическая практика, позволяющая американскому гражданину также состоять в гражданстве другой страны. Иностранец, ставший гражданином США путем натурализации, может сохранить свое прежнее гражданство при условии, что его родная страна не требует, чтобы он отказался от прежнего гражданства. Принятые в конце прошлого века иммиграционные законы, отказывающие американским гражданам в возможности состоять также в иностранном гражданстве, хотя не отменены, тем не менее, не претворяются в жизнь и не охраняются органами власти.

Промежуточное - «нейтрально-негативное» - место занимает, в частности, Бельгия, где натурализующийся человек не обязан отказываться от своего прежнего гражданства. В то же время, урожденный гражданин Бельгии,

\footnotetext{
${ }^{14}$ См. Бархатова Е.Ю. Гражданство и регистрация: Москва, Россия, СНГ. - 2.изд., перераб. и доп. - М.: ТК Велби; Проспект, 2005. - $397 \mathrm{c}$.

Сборник нормативно-правовых актов государств Восточной Европы и Центральной Азии по вопросам гражданства / Управление Верховного Комиссара ООН по делам беженцев / Виктор Андриенко (сост.), Валентина Суботенко (сост.). - К. : УВКБ ООН, 2005. - 600c.

Умови громадянства: Збірка статей / Б. ван Стінберген (ред.), О.О. Іваненко (пер.). - К. : Український Центр духовної культури, 2005. $-264 c$.
}

после достижения зрелости по доброй воле принявший гражданство иной страны, автоматически лишается бельгийского гражданства.

К этой группе тяготеют также страны Прибалтики. Так, в Литве закон разрешает литовцам иметь второе гражданство (кроме литовского), а представителям национальных меньшинств в этом праве отказывает, прадлагая либо отказ от гражданства Литвы либо от гражданства иной страны. Граждане Эстонии делятся на граждан по рождению и лиц, получивших гражданство после прохождения специальной процедуры натурализации. Разница между этими двумя видами до недавних времен заключалась прежде всего в том, что гражданина по рождению нельзя лишить эстонского гражданства. Закон, принятый в 1995 г., запретил двойное гражданство и граждане Эстонии «считаются утратившими гражданство» при принятии гражданства другой страны.

Третья группа государств выступает исключительно за применение принципа одного гражданства (Германия, Швеция, Чехия, Норвегия, Дания и др.). Так, в Германии действует законодательный запрет на второе гражданство - обладатели паспорта Германии должны отказаться от гражданства Германии, если они хотят получить другое гражданство. Но, вместе с тем, обладатели гражданства Германии могут легально оформлять себе вид на жительство или ПМЖ в других странах.

К «негативной» групе можно также отнести и практически все (за исключенитем Молдовы) страны СНГ (Грузию, Россию, Украину и пр.).

Так, Органический закон Грузии о гражданстве гласит, что «В Грузии установлено единое гражданство» (ст. 1. п. 1), и «Гражданин Грузии не может одновременно являться гражданином другого государства, кроме установленного Конституцией Грузии исключительного случая. Президент Грузии может предоставить гражданство Грузии иностранному гражданину, который имеет особые заслуги перед Грузией или предоставление гражданства Грузии которому исходит из государственных интересов» (ст. 1. п. 2).

Гражданин Республики Беларусь может обрести иное гражданство, например, если он длительное время проживает за пределами Беларуси и закон страны, где он проживает, предоставляет ему такую возможность. Сам факт приобретения иностранного гражданства не влечет автоматической утраты гражданства Беларуси. При этом, согласно Закону о гражданстве, вступившем в силу в августе 2002 г., за беларуским гражданином не признается принадлежность к гражданству иностранного государства.

Лицо с двойным гражданством признается в Армении только как гражданин Республики Армения. Эта норма распространяется также на граждан республики, которые в обход нормы с 1 января 1995 г. вышли из гражданства Армении, приняли или получили гражданство других 
DOI: $10.7256 / 1811-9018.2013 .8 .2358$

При цитировании этой статьи сноска на dоі обязательна

\section{Право и политика 8 (164) • 2013}

стран, а также отказались в одностороннем порядке от гражданства Армении.

Среди государств, которые тяготеют к этой группе, особый интерес среди которых для нас представляют Россия и Украина.

Формирование института гражданства в Украине началось из Декларации о государственном суверенитете, содержащей отдельный раздел о гражданстве. Вопрос, связанные с гражданством Украины, регламентируются на основе Конституции Украины (ст.4 которой запрещает гражданам иметь два или более гражданств), Закона Украины «О гражданстве Украины» (18 января 2001 г. $)^{15}$, международных договоров и Указа Президента Украины «О порядке рассмотрения вопросов, связанных с гражданством Украины» (31 марта 1992 г.). Еще в первоначальной редакции статьи 10 Закона Украины «О гражданстве» $(8$ октября 1991 г.) было зафиксировано положение, согласно которому «За лицом, являющемся гражданином Украины, не признается принадлежность к гражданству иностранного государства». Вместе с тем, упомянутая версия Закона (ныне не имеющая юридической силы) предполагала возможность возникновения двойного гражданства на основании международных соглашений Украины. В данное время наличие за гражданином Украины двойного гражданства не признается.

В нормативных документах наших стран не оговорено, что лицо, приобретающее гражданство страны, с которой у России или Украины не заключен договор об урегулировании вопросов двойного гражданства, должно обязательно выйти из российского или украинского гражданства (так будет юридически грамотно, а в противном случае государство (Украина или Россия) будет признавать этого человека только в качестве гражданина своей страны.

\section{Социально-политические аспекты гражданства в контексте гуманитарного развития «постсоветского пространства»}

По статистическим данным в России проживает близко 10 млн. человек, идентифицирующих себя как «украинцы», в Приднестровье таких насчитывается до 50 тысяч. В случае реализации проекта «двойного гражданства» они автоматически смогут претендовать на право получения гражданства Украины и пользование его преимуществами. К этим потенциальным преимуществам в частности относится целый спектр правоотношений, которое Украине практически будет реализовать очень сложно - от обеспечения избирательных прав (необходимость в организации дополнительных избирательных

${ }^{15}$ См. Закон Украӥни «Про громадянство України» // Відомості Верховної Ради України. - 2001. - № 13. - ст.65. участков) до предоставления консульской защиты, всего спектра консульских услуг и т.п.

Ситуацию усложняет тот факт, что Россия видся государством, реализующим проект двойного гражданства в т.ч. в качестве фактора (ре)интеграции постсоветского пространства (в рамках доминирования России) ${ }^{16}$. Показателен в этом смысле подход Дм. Медведева, презентованный им еще в декабре 2006 г. на I-м форуме национальных СМИ стран СНГ и Балтии. Согласно ему, вопросу внедрения двойного гражданства в России со странами СНГ может быть актуален при уровне интеграции, сопоставимом с уровнем Евросоюза: «Если уровень нашей интеграции поднимется несравненно выше и отношения выйдут на уровень, сопоставимый с интеграцией в ЕС, тогда можно говорить о наличии некоего общего гражданства, которое существует в масштабах ЕC». Контекст такого подхода свидетельствует, что современнаяроссийская политико-правовая мысль привязывает эту проблему к «качественно новому» измерению интеграции в рамках СНГ.

Так, в России полностью легализован вопрос двойного гражданства с Туркменией и Таджикистаном. Относительно других стран (в частности Украины), то их гражданам хотя и не запрещено иметь второе гражданство и второй паспорт, но владельцы двух или даже нескольких гражданств не рассматриваются российской властью на своей территории как «двойные граждане» (что ведет к своеобразному «правовому вакууму»).

\section{Европейская интеграция как фактор влияния на проблему гражданства}

Лицо, имеющее двойное гражданство, находясь на территории одного из государств, в гражданстве которой она находится, как правило, не может ссылаться на свои обязательства относительно другой государства. Каждое государство, гражданином которого является бипатрид (лицо, имеющее два или больее гражданств), имеет право считать его своим гражданином и требовать от него выполнения соответствующих обязанностей. Еще в Конвенции, регулирующей некоторые вопросы, связанные с коллизией законов о гражданстве, 1930 г., принятой под эгидой Лиги наций, было установлено, что «Каждое государство само определяет в соответствии со своим законом, кто является его гражданами» (ст. 1).

От института бипатридов, следует отличать институт двойного гражданства, присущего некоторым «сложным»

\footnotetext{
${ }^{16}$ См. Полтораков О.Ю. Адаптація розвитку «простору СНД» до умов глобалізації // Глобалізація і глобальне управління: історичний, соціальний та політологічний виміри. Матеріали міжвідомчої науково-практичної конференції / Відп. ред. С.О. Шергін - К.: Центр вільної преси, 2009.
} 
государствам. Так, двойное гражданство было характерно для граждан СССР, потому что они были гражданами Союза и гражданами его субъектов (союзных республик).

Эволюция отношения к многогражданству прошла в Европе от Конвенции членов Совета Европы «О сокращении случаев многогражданства» (1963 г.) до современного положения ${ }^{17}$. На основании статьи 8 (1) Договора о Европейском Союзе, «каждый гражданин страны-члена ЕС является гражданином союза; он имеет двойное гражданство - национальное и гражданство Европы».

Кроме того, например, правительство Румынии в рамках идеологии «восстановления исторической справедливости» прилагает серьезные усилия по предоставлению права на получения румынского гражданства всем проживающим в пределах границ т.н. «Большой (или Великой) Румынии» (Romania Mare) образца 1940 г. В контексте напряженности в этнонациональных отношениях, характерной для сегодняшней Румынии, данная тенденция отрицательно сказывается на развитии этнонациональных процессов в странах - ее соседях (в частности Украине).

В украинском контексте следует обратить внимание на вступление в силу в 2006 году Закона Украины «О ратификации Европейской конвенции о гражданстве». Законом ратифицирована Европейская конвенция о гражданстве, призванная содействовать адаптации национального законодательства к европейским принципам и правилам относительно гражданства физических лиц. Глава же V Конвенции, регулируя вопрос множественного гражданства, предусматривает обязательство государствучастников позволять своим гражданам сохранять разные гражданства, приобретенные при рождении или в связи со вступлением в брак. Вместе с тем, статья 15 Конвенции не ограничивает право каждого государства обусловливать обретение или сохранение его гражданства требованием отказа или утери лицом гражданства другого государства. Отмеченное положение отвечает требованиям национального законодательства Украины ${ }^{18}$. Украина ратифицирует указанную Конвенцию с оговоркой о неприменении ее главы VII «Военная обязанность в случаях множественного гражданства», как противоречащей положениям ст. 65 Конституции Украины и ст. 1 Закона Украины «О всеобщей воинской повинности и военной службе».

\section{Выводы}

Институт двойного гражданства порождает гуманитарно-политические разногласия и политико-правовые коллизии прежде всего вследствие разного объема

\footnotetext{
${ }^{17}$ См. Рубач Л., Мілорава М., Коцюба В. Громадянство: набуття та припинення / Центр правових досліджень Фурси. - К. : Видавець Фурса С.Я., 2006. - 68c.

${ }^{18}$ Ср. Закон України «Про громадянство України» // Відомості Верховної Ради України. - 2001. - № 13. - ст.65.
}

прав и свобод, которыми бипатриды (лица с двумя гражданствами) могут реально пользоваться по месту проживания и на которые они имеют право согласно законам своей (этнической и т.п.) родины, гражданами которой они также остаются. Вследствие этого на протяжении последних полутора столетий в практике межгосударственных отношений сложилась тенденция избегать применение института двойного гражданства, а в случае невозможности - пользоваться им только на основе двусторонних соглашений.

1. С сугубо юридической точки зрения наиболее неурегулированым вопросом является двойное гражданство граждан Украины (в частности П. Лазаренко), получивших этот статус до 1995 г. Тем более, что согласно Конституции Украины лишить гражданства Украины (даже в случае откровенных нарушений) почти невозможно. На фоне, в частности, упрощенной процедуры получения гражданства в таких странах как Румыния или РФ (несмотря на определенные ограничения, появившиеся в последние годы), несколько обостряется угроза постепенного «размывания» гражданства для таких стран как Молдова или Украина.

2. Двойное гражданство для большинства стран СНГ является вызовом социогуманитарной составляющей их национальной безопасности. Введение института двойного гражданства в рамках СНГ (даже на уровне отдельных стран) означает, что не только «свои» граждане смогут получать гражданства других стран, но и граждане других стран (тех же стран СНГ, которые исторически являются наиболее родственными) будут претендовать на гражданство. Это уже порождает ряд вызово национальной и региональной безопасности - начиная с «полулегальной» миграции и заканчивая проблемами организации выбора в «зарубежном избирательном округе». Так, наличие паспорта Украины автоматически гарантирует индивиду (бипатриду) право голосовать на выборах всех уровней. В условиях недостаточного урегулированного избирательного законодательства и отсутствия единого реестра избирателей, характерного для таких стран как Украины, это порождает проблемы как организации выборов, так и дальнейшей легитимизации их результатов.

3. Переведение проблемы двойного гражданства в практическую международно-правовую плоскость может состояться лишь процедурным путем подписания двусторонних международных договоров с теми странами, которые признают и допускают институт двойного гражданства. После этого должен состояться процедура их ратификации Парламентами соответствующих стран. Лишь после этого следует вносить изменения в национальное законодательство (прежде всего в Конституцию и в Закон «О гражданстве»).

4. Наличие двойного гражданства может косвенно выступать вызовом политико-экономической безопасно- 
DOI: 10.7256/1811-9018.2013.8.2358

При цитировании этой статьи сноска на ооі обязательна

\section{Право и политика 8 (164) 2013}

сти и угрозой - безопасности социально-экономической. Оно - особенно в условиях масштабного кризиса - опосредованно стимулирует утечку трудовых ресурсов из менее экономически развитых стран в более развитые. Так, экономика Украины уже ощущает недостаток квалифицированных кадров разной квалификации (средний гражданин трудоспособного возраста Украины за свою жизнь увеличивает ВВП страны в среднем на 200 тыс. долл.).

5. Для решения многих политико-правовых проблем, связанных с двойным гражданством, наиболее эффективным видится использование политико-правового принципа определения «эффективного гражданства». «Эффективное гражданство» связано с необходимостью определения фактического или преобладающего гражданства бипатрида для решения проблем, связанных с коллизионной формулой прикрепления, определяющей личностный статус физического лица. В этом случае следует исходить из места постоянного проживания лица, его работы, местонахождения его имущества (прежде всего недвижимого), проживания его семьи и т.п. Это, например, крайне актуализируется для современной Европе, где существуют «прозрачные» межгосударственные границы (в сущности, упраздненные для граждан ЕC) и наблюдается «внутренняя» миграция населения в пределах Европейского Союза.

\section{Библиография:}

1. Бархатова Е.Ю. Гражданство и регистрация: Москва, Россия, СНГ. - 2.изд., перераб. и доп. - М.: ТК Велби; Проспект, 2005. - 397 с.

2. Бедрій Р.Б. Громадянство України: конституційноправові основи: Автореф. дис... канд. юрид. наук: 12.00.02 / Національна академія внутрішніх справ України. - К., 2005. - 16 с.

3. Белов А.В. Двойное гражданство и проблема лояльности // Правоведение. - 2002. - № 2. - С. 157-161.

4. Белов А.В. Международно-правовые аспекты двойного гражданства : Автореферат диссертации на соискание ученой степени кандидата юридических наук. Специальность 12.00.10 - Международное право ; Европейское право / Санкт-Петербургский государственный университет. - СПб., 2002. - 23 с.

5. Выхованец О. Институт гражданства как инструмент построения Русского мира // http://www.antropotok. archipelag.ru/text/a221.htm

6. Европейская конвенция о гражданстве от 6 ноября 1997 г. // European Treaty Series. - № 166.

7. Закон України «Про громадянство України»// Відомості Верховної Ради України. - 2001. - № 13. - ст.65.
8. Кокошин А.А. Реальный суверенитет. - М: Европа, 2006. $-180 \mathrm{c}$.

9. Кутафин О.Е. Российское гражданство. - М. : Юрист, 2004. - 589 c.

10. Полтораков О.Ю. Адаптація розвитку «простору СНД» до умов глобалізації // Глобалізація і глобальне управління: історичний, соціальний та політологічний виміри. Матеріали міжвідомчої науково-практичної конференції / Відп. ред. С.О. Шергін - К.: Центр вільної преси, 2009.

11. Полтораков А.Ю. «Европейская идентичность»и и «европейские ценности» в политико-правовом поле Европейского Союза // Цивилизационная структура современного мира. Коллективная монография. / Под ред. ак. НАН Украины Ю. Пахомова и д.филос.н. Ю. Павленко - К.: Наукова думка, 2007. - Т.II. Макрохристианский мир в эпоху глобализации.

12. Полтораков А.Ю. Цивилизационные проблемы западноевропейской интеграции и вопросы национальногосударственной идентичности // Цивилизационная структура современного мира. Коллективная монография. / Под ред. ак. НАН Украины Ю. Пахомова и д.филос.н. Ю. Павленко - К.: Наукова думка, 2007. - Т.ІІ.Макрохристианский мир в эпоху глобализации.

13. Прибыткова И. Влияние института гражданства на процессы возвращения и обустройства ранее депортированных народов и лиц в Крыму. - К., 1997. - 204c.

14. Рубач Л., Мілорава М., Коцюба В. Громадянство: набуття та припинення / Центр правових досліджень Фурси. - К. : Видавець Фурса С.Я., 2006. - 68c.

15. Сборник нормативно-правовых актов государств Восточной Европы и Центральной Азии по вопросам гражданства / Управление Верховного Комиссара ООН по делам беженцев / Виктор Андриенко (сост.), Валентина Суботенко (сост.). - К. : УВКБ ООН, 2005. - 600с.

16. Суверенитет: Антология. - М.: Европа, 2007. - 304 с.

17. Умови громадянства: Збірка статей / Б. ван Стінберген (ред.), О.О. Іваненко (пер.). - К. : Український Центр духовної культури, 2005. - 264c.

18. Федеральный закон Российской Федерации «О гражданстве Российской Федерации» от 31 мая 2002 г. № 62-Ф3 // Российская газета. - 2002. - 5 июня. - № 100.

\section{References (transliteration):}

1. Barhatova E.Yu. Grazhdanstvo i registraciya: Moskva, Rossiya, SNG. - 2.izd., pererab. i dop. - M.: TK Velbi; Prospekt, 2005. - 397 s.

2. Bedriy R.B. Gromadyanstvo Ukraïni: konstituciynopravovi osnovi: Avtoref. dis... kand. yurid. nauk: 12.00.02 / Nacional'na akademiya vnutrishnih sprav Ukraïni. - K., 2005. - $16 \mathrm{~s}$. 
DOI: $10.7256 / 1811-9018.2013 .8 .2358$

При цитировании этой статьи сноска на doi обязательна

Трансформация правовых и политических систем

3. Belov A.V. Dvoynoe grazhdanstvo i problema loyal'nosti // Pravovedenie. - 2002. - № 2. - S. 157-161.

4. Belov A.V. Mezhdunarodno-pravovye aspekty dvoynogo grazhdanstva : Avtoreferat dissertacii na soiskanie uchenoy stepeni kandidata yuridicheskih nauk. Special'nost' 12.00.10 - Mezhdunarodnoe pravo ; Evropeyskoe pravo / Sankt-Peterburgskiy gosudarstvennyy universitet. - SPb., 2002. $-23 \mathrm{~s}$.

5. Vyhovanec O. Institut grazhdanstva kak instrument postroeniya Russkogo mira // http://www.antropotok. archipelag.ru/text/a221.htm

6. Kokoshin A.A. Real'nyy suverenitet. - M: Evropa, 2006. $-180 \mathrm{~s}$.

7. Kutafin O.E. Rossiyskoe grazhdanstvo. - M. : Yurist, 2004. - 589 s.

8. Poltorakov O.Yu. Adaptaciya rozvitku «prostoru SND» do umov globalizaciï // Globalizaciya i global'ne upravlinnya: istorichniy, social'niy ta politologichniy vimiri. Materiali mizhvidomchoï naukovo-praktichnoï konferenciï / Vidp. red. S.O. Shergin - K.: Centr vil'noï presi, 2009.
9. Poltorakov A.Yu. «Evropeyskaya identichnost'»i «evropeyskie cennosti»v politiko-pravovom pole Evropeyskogo Soyuza // Civilizacionnaya struktura sovremennogo mira. Kollektivnaya monografiya. / Pod red. ak. NAN Ukrainy Yu. Pahomova i d.filos.n. Yu. Pavlenko - K.: Naukova dumka, 2007. - T.II. Makrohristianskiy mir v epohu globalizacii.

10. Poltorakov A.Yu. Civilizacionnye problemy zapadnoevropeyskoy integracii i voprosy nacional'no-gosudarstvennoy identichnosti // Civilizacionnaya struktura sovremennogo mira. Kollektivnaya monografiya. / Pod red. ak. NAN Ukrainy Yu. Pahomova i d.filos.n. Yu. Pavlenko - K.: Naukova dumka, 2007. - T.II.Makrohristianskiy mir v epohu globalizacii.

11. Pribytkova I. Vliyanie instituta grazhdanstva na processy vozvrascheniya i obustroystva ranee deportirovannyh narodov i lic v Krymu. - K., 1997. - 204s.

12. Rubach L., Milorava M., Kocyuba V. Gromadyanstvo: nabuttya ta pripinennya / Centr pravovih doslidzhen' Fursi. - K. : Vidavec' Fursa S.Ya., 2006. - 68s. 